\title{
Experience with the modified Blalock-Taussig operation using polytetrafluoroethylene (Impra) grafts
}

\author{
P H KAY, A CAPUANI, R FRANKS, C LINCOLN \\ From The Brompton Hospital, Fulham Road, London
}

SUMMARY Between June 1978 and January 1982, 115 patients underwent 122 subclavian arterypulmonary artery shunts using polytetrafluoroethylene (PTFE Impra) grafts. Forty-six of the patients had a ductus dependent pulmonary circulation, the patency of which was maintained by an infusion of prostaglandin $\mathrm{E}_{2}$ in 29 cases. There were nine hospital deaths, four of which were related to shunt failure. Five patients underwent a second shunt procedure within one week of the first. There were two cases of late graft occlusion. Twelve shunts were considered to have failed. The actuarial estimate of shunt patency was $90 \%$ ( $\pm 3 \%$ ) at two years for all patients and $74 \%( \pm 10 \%)$ for neonates. There was no statistically significant difference in two year shunt patency between $4 \mathrm{~mm}$ grafts (88 $\pm 5 \%)$ and $6 \mathrm{~mm}$ grafts $(96 \pm 3 \%)$.

The modified Blalock shunt using a PTFE graft is an effective pulmonary-systemic shunt with a good short term patency.

Despite the current trend towards early total correction of congenital cardiac defects, this is unsuitable for some patients with cyanotic heart disease. Such patients require a systemic pulmonary shunt, increasing pulmonary blood flow, either as temporary palliation before definitive surgery, or occasionally as a more permanent feature in conditions which we consider "uncorrectable" at the present time.

The problems of existing shunt procedures are well known. ${ }^{12}$ Following the recent report of the modified Blalock shunt ${ }^{3}$ we present the use of polytetrafluoroethylene (PTFE Impra) grafts for systemic pulmonary shunts in 115 patients with cyanotic congenital heart disease.

\section{Patients and methods}

During the period June 1978 to January 1982, 122 modified Blalock shunts were performed in 115 patients at the Brompton Hospital. The median age was 4 months (range 1 day to 28 years). Twenty-four neonates underwent operation in the first week of life and a further 18 between 1 week and 1 month. The median weight was $4.5 \mathrm{~kg}$ (range 2.1 to $55 \mathrm{~kg}$ ). Sixtytwo $(54 \%)$ of the patients were male.

Accepted for publication 18 December 1982
In ali cases, the indication for surgery was hypoxaemia caused by partially or completely obstructed pulmonary blood flow. The underlying cardiac conditions are shown in Table 1 . The pulmonary circulation was dependent on a persistent ductus arteriosus in 46 patients. Ten patients had undergone previous shunt operations (eight Blalock-Taussig and two Waterston) between two and four years previously. These patients required a second shunt procedure for increasing cyanosis. Nine of the shunts were widely patent but one Blalock-Taussig shunt was narrowed at the pulmonary artery anastomosis.

\section{Table 1 Intracardiac pathology}

\begin{tabular}{lr}
\hline Diagnosis & No. \\
\hline Univentricular heart & 34 \\
Pulmonary atresia + VSD & 22 \\
Tetralogy of Fallot & 20 \\
Double outlet right ventricle & 12 \\
Pulmonary atresia + IVS & 12 \\
Concordant TGA & 8 \\
Discordant TGA & 2 \\
Tricuspid atresia & 2 \\
Others & 3 \\
\hline
\end{tabular}

VSD, ventricular septal defect; IVS, intact ventricular septum; TGA, transposition of the great arteries. 
All modified Blalock shunts were performed as urgent elective procedures with the patient in a stable condition. Twenty-nine patients were receiving an infusion of prostaglandin $E_{2}(0.01-0.1 \mu \mathrm{g} / \mathrm{kg}$ per $\mathrm{min}$ ) to maintain the patency of the ductus arteriosus. Twenty patients required intermittent positive pressure ventilation before surgery.

\section{SURGICAL TECHNIQUE}

When there was no discrepancy between the sizes of the pulmonary arteries a modified Blalock shunt was technically easier to perform on the left. In the presence of a ductus dependent pulmonary circulation, however, the side opposite the ductus was chosen. The initial modified Blalock shunt was performed on the right in 65 patients and on the left in 50 patients.

The chest was opened through a lateral thoracotomy through the fourth intercostal space. The size of the graft was related to the existing anatomy; normally the largest diameter graft that could be conveniently anastomosed to the suclavian and pulmonary arteries was chosen. The upper anastomosis was constucted between the obliquely cut end of the graft and a longitudinal incision in the subcla- vian artery using continuous 6/0 Prolene. An ellipse of $\frac{0}{7}$ the upper margin of the pulmonary artery was excised $c$. before construction of the lower anastomosis with the $\vec{F}$ transversely cut end of the graft.

The patients were anticoagulated with heparin (1을 $\mathrm{mg} / \mathrm{kg}$ ) before opening the subclavian artery, and this was continued six hourly for 48 hours. The patients? then received antiplatelet therapy with aspirin $(8 \mathrm{mg} / \mathbb{Q}$ $\mathrm{kg}$, t.d.s.) and dipyridamole $(1.25 \mathrm{mg} / \mathrm{kg}$, t.d.s.) for three months.

\section{Results}

HOSPITAL MORTALITY

Nine (8\%) patients died before leaving hospital up to three months after their original shunt proceduret (Table 2). In four cases (Table 2, cases 1, 2, 3, and 9) this was directly related to shunt failure.

\section{INADEQUATE PALLIATION BY MODIFIED}

BLALOCK SHUNT

Three patients (Table 2, cases 1, 2, and 3) died of hypoxaemia within one week of operation, indicating $\overrightarrow{0}$ that the shunts were inadequate. One of the patientsw

Table 2 Hospital mortality

\begin{tabular}{|c|c|c|c|c|c|c|}
\hline $\begin{array}{l}\text { Case } \\
\text { No. }\end{array}$ & Diagnosis & $\begin{array}{l}\text { Weight } \\
(\boldsymbol{k g})\end{array}$ & $\begin{array}{l}\text { Conduit size } \\
(\mathrm{mm})\end{array}$ & $\begin{array}{l}\text { Time of } \\
\text { death }(d)\end{array}$ & Cause of death & $\begin{array}{l}\text { State of shunt } \\
\text { at necropsy }\end{array}$ \\
\hline $\begin{array}{l}1 \\
2 \\
3 \\
4 \\
5\end{array}$ & $\begin{array}{l}\text { Pulmonary atresia + VSD } \\
\text { Pulmonary atresia + VSD } \\
\text { Univentricular heart } \\
\text { Double outlet right ventricle } \\
\text { Hypoplastic left ventricle } \\
\text { PAPVD }\end{array}$ & $\begin{array}{r}4 \cdot 0 \\
3 \cdot 2 \\
6 \cdot 0 \\
10 \cdot 4 \\
3 \cdot 0\end{array}$ & $\begin{array}{l}6 \\
4 \\
4 \\
6 \\
5\end{array}$ & $\begin{array}{r}1 \\
1 \\
7 \\
8 \\
13\end{array}$ & $\begin{array}{l}\text { Hypoxia } \\
\text { Hypoxia } \\
\text { Hypoxia } \\
\text { Pulmonary oedema } \\
\text { Pulmonary venous } \\
\text { obstruction }\end{array}$ & $\begin{array}{l}\text { Unknown } \\
\text { Patent } \\
\text { Unknown } \\
\text { Patent } \\
\text { Patent }\end{array}$ \\
\hline 7 & Pulmonary atresia + IVS & $3 \cdot 8$ & 4 & 30 & $\begin{array}{l}\text { Pulmonary oedema, } \\
\text { shunt banded }\end{array}$ & Patent \\
\hline $\begin{array}{l}8 \\
9\end{array}$ & $\begin{array}{l}\text { Univentricular heart } \\
\text { Pulmonary atresia + IVS }\end{array}$ & $\begin{array}{l}5 \cdot 0 \\
3 \cdot 4\end{array}$ & $\begin{array}{l}6 \\
4+4\end{array}$ & $\begin{array}{l}39 \\
90\end{array}$ & $\begin{array}{l}\text { Pneumonia } \\
\text { After RVOT } \\
\text { reconstruction }\end{array}$ & $\begin{array}{l}\text { Patent } \\
\text { Blocked }\end{array}$ \\
\hline
\end{tabular}

VSD, ventricular septal defect; IVS, intact ventricular septum; PDA, persistent ductus arteriosus; PAPVD, partial anomalous pulmonary venous drainage; RVOT, right ventricular outflow tract.

Table 3 Shunt failure

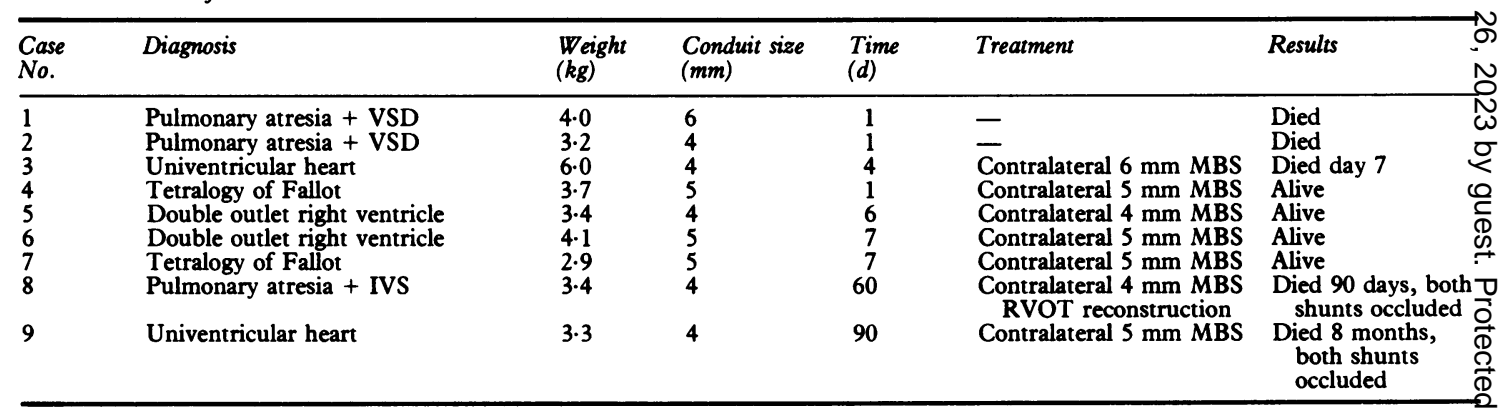

VSD, ventricular septal defect; IVS, intact ventricular septum; RVOT, right ventricular outflow tract; MBS, modified Blalock shunt. 
(case 3) had undergone a second contralateral modified Blalock shunt at four days. Each of these patients had small pulmonary arteries with distal branch stenoses. Four other patients (Table 3, cases 4, 5, 6, and 7) remained hypoxic and required a second shunt procedure within one week of the original modified Blalock shunt. These four patients are alive and awaiting corrective surgery.

LATE OCCLUSION OF MODIFIED BLALOCK SHUNT There were two cases of late graft occlusion, both involving $4 \mathrm{~mm}$ grafts. Both patients underwent a second shunt procedure, though in each case palliation was only temporary. One patient (Table 3, case 9) died suddenly five months after the second shunt and both shunts were found to be occluded at necropsy. The other patient (Table 3, case 8) developed signs of increasing cyanosis and died after a right ventricular outflow tract reconstruction. This patient had remained polycythaemic with a haematocrit of 65 . At necropsy both shunts, together with the inferior vena cava and both iliac arteries, were thrombosed.

\section{EXCESSIVE PULMONARY BLOOD FLOW}

Three hospital deaths were related to excessive pulmonary blood flow after modified Blalock shunts (Table 2). In one patient (case 6) the ductus was ligated and in another (case 7) the shunt banded in an attempt to control pulmonary oedema. The third patient (case 4) died after banding of the shunt and correction of the double outlet right ventricle.

A fourth patient developed excessive pulmonary blood flow and was successfully treated by banding of the shunt. Forty two (45\%) of the 94 surviving patients were receiving diuretics for pulmonary oedema related to excessive pulmonary blood flow before corrective surgery.

\section{LATE DEATHS}

There were 12 late deaths in this series. With the exception of the two patients already described, all shunts were patent at necropsy. In one case, however, there was evidence of neointimal proliferation at the subclavian artery anastomosis (Fig. 1).

\section{TOTAL CORRECTION}

Seven patients in this series have subsequently undergone elective correction of their intracardiac pathology. In each case the modified Blalock shunt was widely patent and simply closed with a single large "Ligaclip".

\section{EFFECTIVENESS OF MODIFIED BLALOCK SHUNT}

Three of the early hospital deaths were related to inadequate shunting despite a bilateral modified Blalock shunt in one case. A further six patients

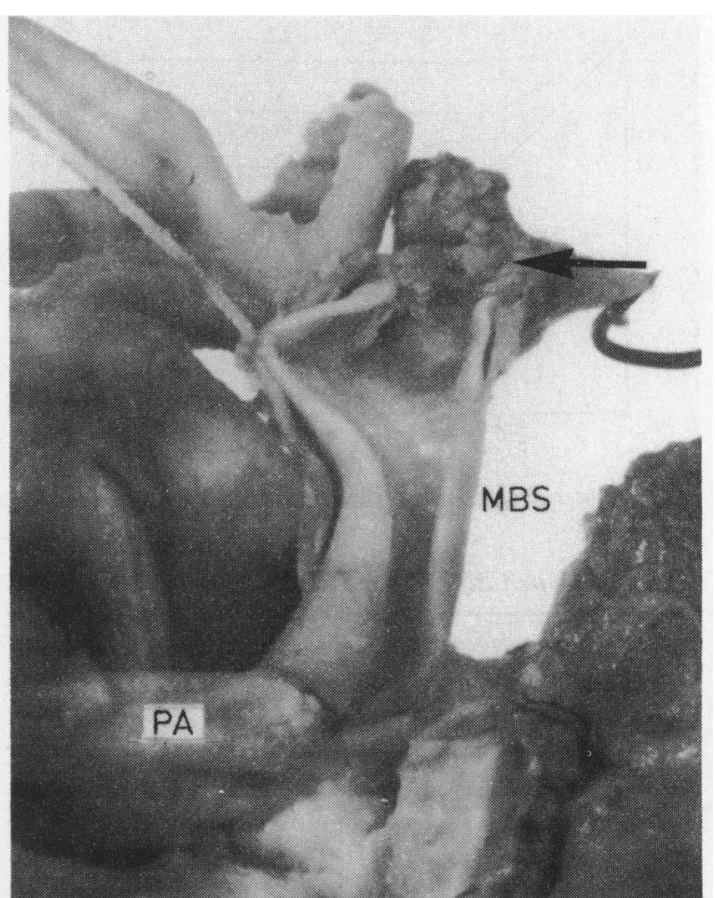

Fig. 1 Modified Blalock shunt (MBS) showing neointimal proliferation (arrow) at the subclavian artery anastomosis. PA, pulmonary artery.

required a second shunt within six months of the original procedure (Table 3). Two of these later died when both shunts were found to be occluded. Thus, 12 of the total 122 shunts were considered inadequate. There have been no reports of shunt occlusion after six months. The actuarial estimate of overall shunt patency is $90 \%( \pm 3 \%)$ at two years. Eleven shunt failures occurred in neonates. Thus an actuarial estimate of shunt patency is $74 \%( \pm 10 \%)$ at two years in this group (Fig. 2).

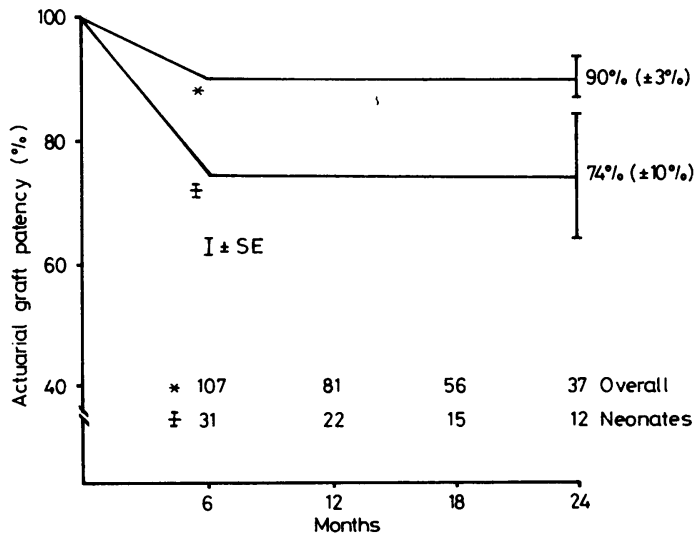

Fig. 2 Patency of modified Blalock shunt. 


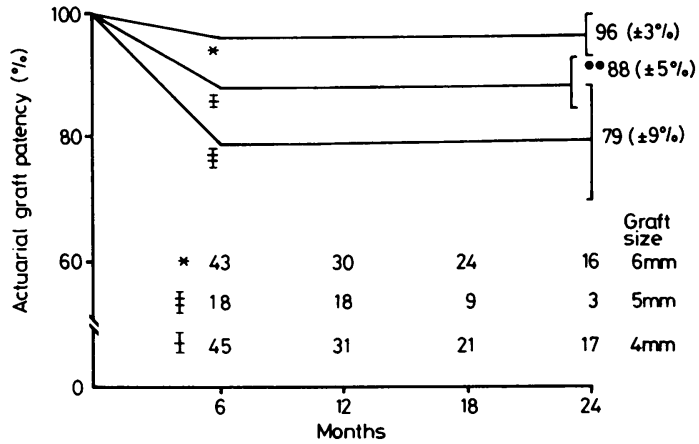

Fig. 3 Patency of modified Blalock shunt related to graft size.

Table 4 Modified Blalock shunt occlusion related to shunt size

\begin{tabular}{lclc}
\hline $\begin{array}{l}\text { Shunt size } \\
(m m)\end{array}$ & No. & Occlusion & Patency \% \\
\hline 4 & 52 & 6 & $88( \pm 5)$ \\
5 & 19 & 4 & $79( \pm 9)$ \\
6 & 45 & 2 & $96( \pm 3)$ \\
8 & 6 & 0 & 100 \\
\hline
\end{tabular}

Table 4 shows the incidence of shunt occlusion in relation to the size of the shunt. The actuarial two year patency rates based on graft size were $88 \%$ ( \pm $5 \%$ ) for $4 \mathrm{~mm}$ grafts, $79 \%$ ( $\pm 9 \%$ ) for $5 \mathrm{~mm}$ grafts, and $96 \%( \pm 3 \%)$ for $6 \mathrm{~mm}$ grafts (Fig. 3). The differ- ence in shunt patency for the $4 \mathrm{~mm}$ and the $6 \mathrm{~mm}$ modified Blalock shunt was not significant $(p=0.2)$.

The shunts proved effective in the surviving patients with mean arterial $\mathrm{Po}_{2}$ significantly raised from $4.6( \pm 1.7) \mathrm{kPa}$ to $7.6( \pm 2.9) \mathrm{kPa}(\mathrm{p}<0.01)$.

\section{Discussion}

Modification of the standard Blalock-Taussig shunt ${ }^{4}$ using a prosthetic tube was first described by Klinner and colleagues 5 in 1962. It was developed to avoid the problems of growth retardation associated with ligation of the subclavian artery. ${ }^{6-8}$ Subsequently there have been several favourable reports of PTFE grafts used for aortopulmonary shunts in all ages..$^{9-11}$

Our overall patency rate of $90 \%( \pm 3 \%)$ at two years compares favourably with other series. ${ }^{3}$ The $74 \%$ ( \pm $10 \%)$ two year patency rate in the surviving neonates was particularly encouraging. The use of prostaglandin $E_{2}$ to maintain the patency of the ductus arteriosus in the neonates has obviated the need for emergency shunt procedures. ${ }^{12-14}$ Indeed, all operations described in this series were performed as urgent elective cases.

Clearly, the pulmonary vascular resistance and in particular the presence of distal stenoses are important causes of early shunt failure. Technical problems are liable to be more crucial with the smaller grafts, though we feel that these have been largely overcome

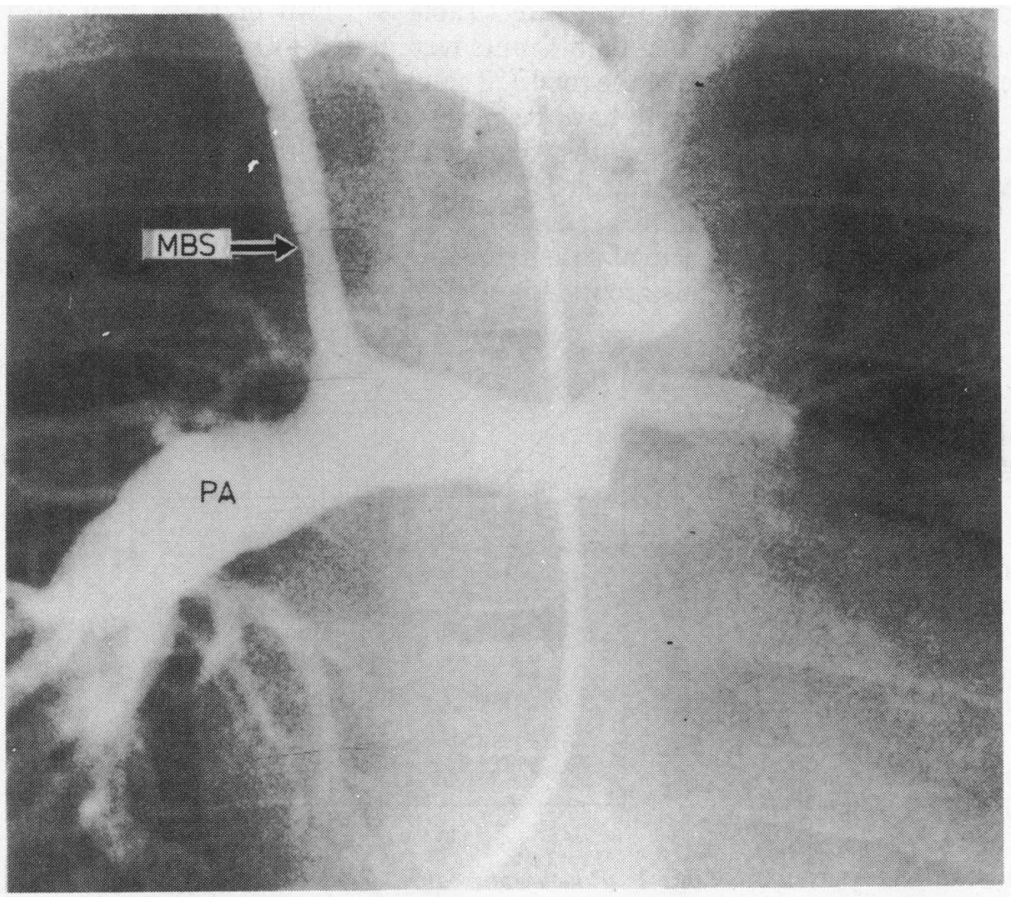

Fig. 4 Angiogram showing $4 \mathrm{~mm}$ modified Blalock shunt four years after insertion (arrow). 
with the application of microvascular surgical techniques. Indeed, there was no significant difference in shunt patency between the $4 \mathrm{~mm}$ grafts and $6 \mathrm{~mm}$ grafts at two years.

The high patency rate is a striking feature of this series and may be related to the routine use of antiplatelet therapy ${ }^{15}$ for three months, inhibiting platelet deposition and excessive neointimal proliferation at the anastomoses (Fig. 1). In addition, after a bilateral shunt occlusion together with inferior vena caval and iliac artery thromboses in a patient with a persistently raised haematocrit, we have adopted a policy of venesection and plasma replacement at the time of surgery to maintain the haematocrit below $45 \%$.

Forty two (45\%) surviving patients required diuretics. In addition, four patients had such excessive blood flow to the lungs after the modified Blalock shunt that they required further surgery. This occurred irrespective of the size of the graft, indicating that while the subclavian artery regulates pulmonary blood flow in the majority of cases this is not universal.

Finally, the long term fate of the modified Blalock shunt remains in doubt. Fig. 4 shows an angiogram of a $4 \mathrm{~mm}$ shunt four years after surgery showing no evidence of distortion at the pulmonary anastomosis. This may, however, become a problem as the child grows, resulting in a further reduction in blood flow through the shunt which is no longer limited by the diameter of the subclavian artery but by that of the shunt itself.

\section{Conclusions}

The modified Blalock shunt using a polytetrafluoroethylene graft is an effective pulmonarysystemic shunt with a good short term patency. In general, the largest graft that can be tailored to the anatomy should be used. Antiplatelet therapy with dipyridamole and aspirin for three months after operation may increase graft patency. Ligation of the shunt is simply achieved with a single "Ligaclip". The long term fate of the modified Blalock shunt is unknown. Thus, we only recommend its use in those patients who are likely to undergo corrective surgery at a later date.

\section{References}

1 Kirklin JW, Blackstone EH, Pacifico AD, Brown RN, Bageron LM Jr. Routine primary repair vs two-stage repair for tetralogy of Fallot. Circulation 1979; 60: 37386.

2 Stephenson LW, Friedman S, Edmunds LH Jr. Staged surgical management of tetralogy of Fallot in infants. Circulation 1978; 58: 837-41.

3 de Leval MR, McKay R, Jones M, Stark M, Macartney FJ. Modified Blalock-Taussig shunt. $\mathcal{F}$ Thorac Cardiovasc Surg 1981; 81: 112-9.

4 Blalock A, Taussig HB. The surgical treatment of malformations of the heart in which there is pulmonary stenosis or pulmonary atresia. $\mathcal{F A M A} 1$ 1945; 128: 189 202.

5 Klinner W, Pasini M, Schaudig A. Anastomose zwishen System-und Lungenarterie mit Hilfe von Kunststoffprothesen bei cyanotischen Herzvitien. Thoraxchir Vask Chir 1962; 10: 68-75.

6 Todd PJ, Wright JGC, Hamilton DI, Dangerfield P, Wilkinson JL. Late effects on the left upper limb of subclavian flap aortoplasty. $\mathcal{F}$ Thorac Cardiovasc Surg.

7 Harris AM, Segel N, Bishop JM. Blalock-Taussig anastomosis for tetralogy of Fallot. A 10-15 year follow-up. Br Heart $\mathcal{F}$ 1964; 26: 266-73.

8 Currarino G, Engle MA. The effects of ligation of the subclavian artery on the bones and soft tissues of the arms. F Pediatr 1965; 67: 808-11.

9 Gazzaniga AB, Lamberti JJ, Siewers RD, et al. Arterial prosthesis of microporous expanded PTFE for construction of aorta-pulmonary shunts. $\mathcal{F}$ Thorac Cardiovasc Surg 1976; 72: 357-63.

10 Jennings RB Jr, Innes BJ, Brickman RD. Use of microporous expanded PTFE grafts for aorta-pulmonary shunts in infants with complex cyanotic heart disease. $\mathcal{F}$ Thorac Cardiovasc Surg 1978; 76: 489-94.

11 Miyamoto K, Zavonella C, Lewin AN, Subramanian S. Aorta-pulmonary artery shunts with expanded PTFE tube. Ann Thorac Surg 1979; 27: 413-7.

12 Elliott RB, Starling MB, Neutze JM. Medical manipulation of the ductus arteriosus. Lancet 1975; i: 140-2.

13 Browdie DA, Norberg W, Agnew R, Altenburg B, Ignacio $R$, Hamilton $C$. The use of prostaglandin $E_{1}$ and Blalock-Taussig shunts in neonates with cyanotic congenital heart disease. Ann Thorac Surg 1979; 27: 508-13.

14 Donahoo JS, Roland JM, Kan J, Gardner TJ, Kidd BSL. Prostaglandin $\mathrm{E}_{1}$ as an adjunct to emergency cardiac operations in neonates. $\mathcal{f}$ Thorac Cardiovasc Surg 1981; 81: 227-31.

15 Oblath RW, Buckley FO Jr, Green RM, Schwartz SI, DeWeese JA. Prevention of platelet aggregation and adherence to prosthetic vascular grafts by aspirin and dipyridamole. Surgery 1978; 84: 37-44.

Requests for reprints to Mr C Lincoln, FRCS, Brompton Hospital, Fulham Road, London SW3 6HP. 